\title{
Preventive measures reduce exposure to polycyclic aromatic hydrocarbons at a graphite electrode plant
}

Marco dell'Omo, Giacomo Muzi, Giancarlo Marchionna, Luca Latini, Patrizia Carrieri, Piero Paolemili, Giuseppe Abbritti

\begin{abstract}
Objective-This study assessed the efficacy of preventive measures in a graphite electrode plant aimed at reducing occupational exposure to polycyclic aromatic hydrocarbons (PAHs).

Methods-Electrode workers $(n=146)$ answered a questionnaire and provided an end of shift urine sample. Urinary 1-hydroxypyrene (1-hp $\left.\mathrm{pur}_{\mathrm{ur}}\right)$ a biological marker of exposure to PAHs, was measured by high performance liquid chromatography coupled with: (a) fluorescence detection. 1-Hydroxypyrene concentrations were compared with the concentrations measured before implementing the preventive measures; and $(b)$ those of a control group of 54 men not occupationally exposed to PAHs.
\end{abstract}

Results-After implementation of preventive measures, median concentrations 1-hp $\mathrm{pr}_{\mathrm{ur}}$ were significantly reduced in some groups of workers: by $-24 \%,-37 \%$ and $-30 \%$ in workers at the green electrode unit, one baking impregnation unit, and the laboratory, respectively. In workers at a second baking impregnation unit, in end product finishing and in the power station 1-hp $\mathrm{pu}_{\mathrm{u}}$ concentrations were unchanged. Urinary 1-hp concentrations were still significantly higher in each group of workers than in the control group ( $p<0.001$ for any comparison). Concentrations in the workers varied with the type of job, the highest values being found in workers engaged in the power station, in the two baking impregnation units and in the green electrode unit.

Conclusions-Implementing preventive measures significantly reduced exposure to PAHs at a graphite electrode plant. The reduction in median and peak concentrations of $1-\mathrm{hp}_{\mathrm{ur}}$, which reflects total exposure to, and internal dose of PAHs, was most evident in workers employed in the units where preventive measures had been taken. Despite an overall reduction, further preventive measures are needed to minimise exposure to PAHs and consequently the risk of adverse health effects.

(Occup Environ Med 1998;55:401-406)

Keywords: polycyclic aromatic hydrocarbons; 1-hydroxypyrene; coal tar pitches
Polycyclic aromatic hydrocarbons (PAHs) are ubiquitous contaminants, derived from the combustion, pyrolysis, and pyrosynthesis of organic matter. Environmental exposure mainly derives from inhalation of polluted urban air, mainstream and sidestream cigarette smoke, and food intake, especially smoked and grilled meat or fish. ${ }^{1}$ High occupational exposure to PAHs occurs in industries producing aluminium, coke and graphite electrodes, in road paving, wood impregnation with creosote, roofing, and chimney sweeping, because large quantities of PAHs are contained in, and on heating, are released from, organic materials such as coal tar and coal tar pitches. ${ }^{1-3}$

Epidemiological studies have provided evidence that occupational exposure to coal tar pitches in some industrial settings-for example, aluminium production - may be associated with increased cancer risk. Several individual PAHs found in coal tar pitches have been identified as carcinogenic in animals and are thus suspected of inducing cancer in humans. ${ }^{124}$

Pyrene is a PAH which is usually present in PAH mixtures; urinary 1-hydroxypyrene (1$\mathrm{hp}_{\mathrm{ur}}$ ), its major metabolite, has been proposed as a biomarker for monitoring occupational exposure to PAHs. ${ }^{5-7}$ Although many studies have shown increased $1-\mathrm{hp}_{\mathrm{ur}}$ concentrations in workers employed in coke, aluminium, and carbon electrode production, in foundries, in wood impregnation with creosote, in coal liquefaction, in the oil shale industry, and road paving, ${ }^{6-15}$ only a few studies have evaluated $1-\mathrm{hp}_{\mathrm{ur}}$ concentrations after undertaking preventive measures in a specific industrial setting. ${ }^{16}{ }^{17}$

The present study was carried out at a graphite electrode plant, where workers were exposed to PAHs mainly contained in coal tar pitches. At this plant, biological dosimetry of 1-hp $\mathrm{ur}_{\mathrm{ur}}$ was performed for the first time in 1994, and high concentrations of $1-\mathrm{hp}_{\mathrm{ur}}$ were shown in some groups of workers. ${ }^{18}$ Therefore, preventive measures were taken to reduce exposure to PAHs.

The aim of this study was to assess the efficacy of these preventive measures by comparing current $1-\mathrm{hp}_{\mathrm{ur}}$ values with $(a)$ the 1994 concentrations, and $(b)$ those of a control group of subjects not occupationally exposed.

\section{Materials and methods}

STUDY PLANT AND MANUFACTURING OF GRAPHITE ELECTRODES

The graphite electrode plant is located in Umbria, Central Italy, and produces large electrodes (length $2.5-3 \mathrm{~m}$, diameter about $0.9 \mathrm{~m}$ ) 


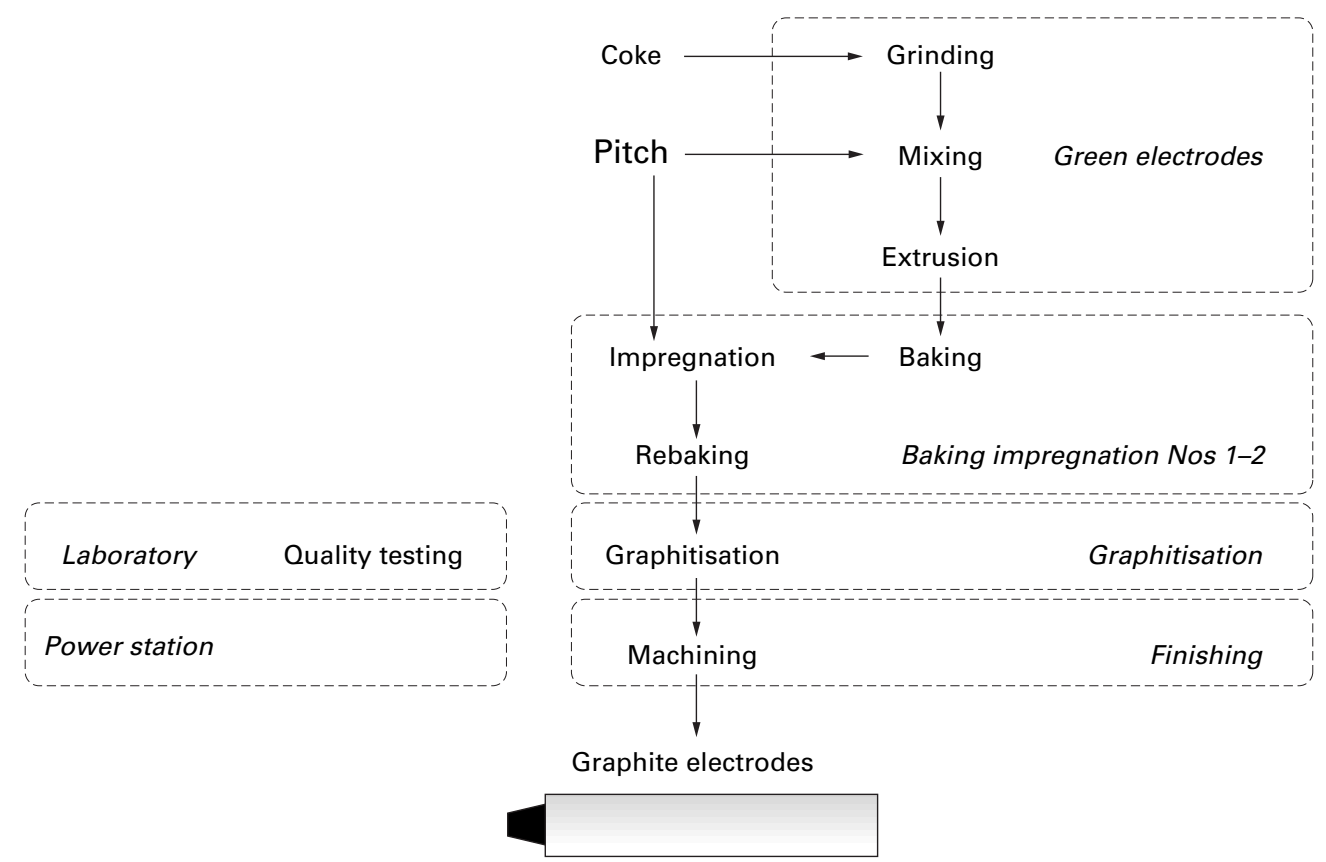

Figure 1 Flow process and production units (italic, bold) at the study plant.

for the electric steel industry. Raw materials are petroleum cokes (fillers) and coal tar pitches (binders), and the main steps in the electrode production are as follows (fig 1).

(1) The coke is ground and sized and then mixed with hot pitch at about $190^{\circ} \mathrm{C}$ to form a semisolid paste, which is cooled, charged in an extrusion press, and extruded at about $110^{\circ} \mathrm{C}$, thus providing crude carbon electrodes (green electrodes) of the final size. The electrodes are then rapidly cooled by immersion in water. This process is performed in the green electrodes unit.

(2) The electrodes are baked in ring furnaces (Hoffmann furnaces) for 20-25 days at a temperature which rises to about $850^{\circ} \mathrm{C}$. The electrodes are then placed in a large metallic basket, preheated in furnaces, put into a pressure tank, and impregnated with liquid pitch at about $250^{\circ} \mathrm{C}$, to fill the open pores. The impregnated electrodes are rebaked in a movable floor furnace. These processes are carried out in two similar baking impregnation units (No 1 and No 2).

(3) The electrodes are coated with graphite by electrical heat treatment at $2800-3000^{\circ} \mathrm{C}$.

(4) The end products are shaped and finished by machine tools.

During the manufacturing process, the handling and heating of raw materials and particularly of the coal tar pitches may cause the release of PAHs in dusts and vapours. Workers are usually highly exposed during steps (1) and (2), but when engaged in steps (3) and (4) are usually less at risk. Moreover, at the plant, some laboratory workers, who extrude, bake, and impregnate smaller electrodes for quality control analysis, and all the workers in the power station, which is fuelled by recycled pitches, are at risk of exposure to PAHs.

All the workers in the plant were tested for exposure to PAHs with $1-\mathrm{hp}_{\mathrm{ur}}$ in $1994,{ }^{18}$ and the following measures to reduce exposure were implemented in 1995-6.

\section{PREVENTIVE MEASURES}

Green electrode unit

A new local exhaust ventilation system was installed over the extrusion press; the existing local exhaust ventilation systems over the scales and the tank containing liquid pitch were checked, cleaned, and refitted; the control room air conditioning system was refitted by moving the fresh air inlet further away from one of the air emission outlets.

\section{Baking impregnation unit No 1}

Instead of being removed from the metallic baskets after impregnation, electrodes were transported in the baskets to the movable floor furnace; here the heating cleaned the encrusted pitch from the baskets before the new preheating and impregnation cycle.

\section{Laboratory}

New local exhaust ventilation systems were installed over the mixer, the cooling tank, and the extrusion press of the crude electrode paste.

\section{STUDY POPULATION AND ANALYSIS OF URINARY} 1-HYDROXYPYRENE

In December 1996, all the workers $(n=146)$ at the green electrode unit, baking impregnation units Nos 1 and 2, finishing, laboratory, and power station units answered a questionnaire about smoking habits and current jobs. They also provided urine samples at the end of the working week for $1-h p_{u r}$ measurement.

Only data from the 103 workers with the same smoking habit as in 1994, who were still performing the same job were compared with

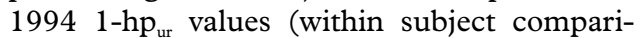
sons). 


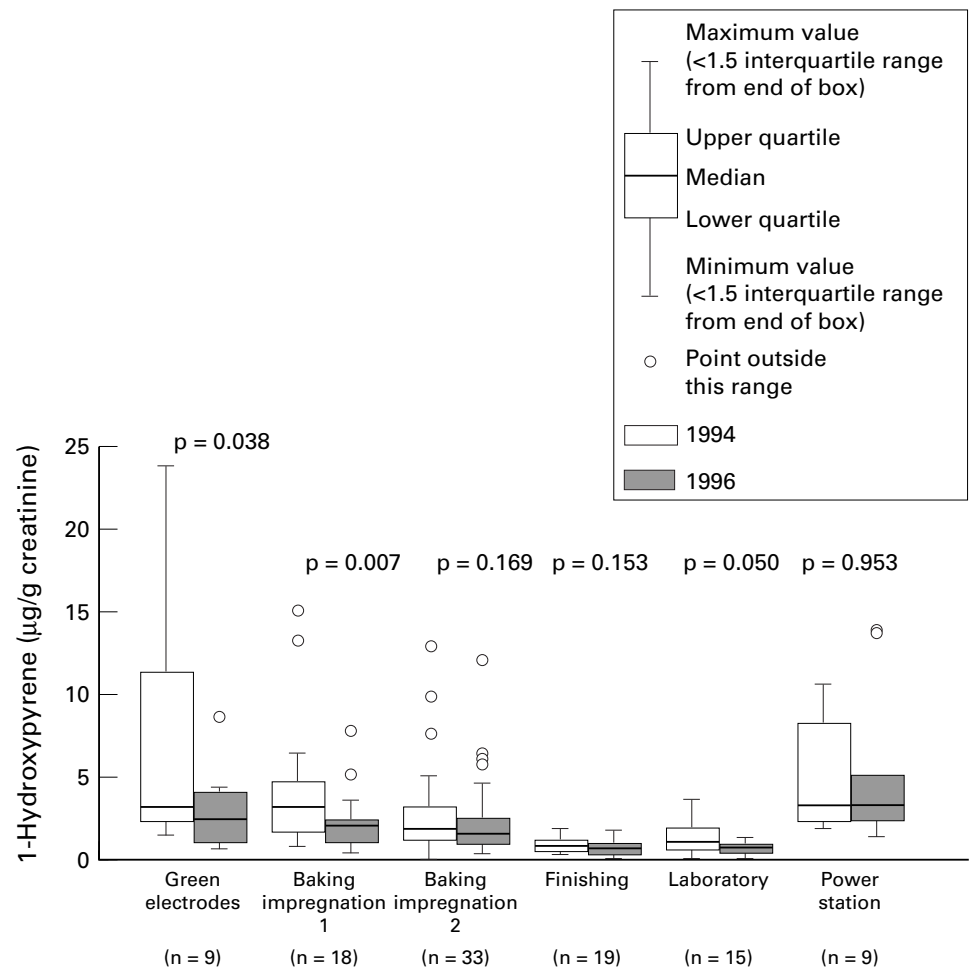

Figure 2 Urinary 1-hydroxypyrene concentrations in electrode plant workers before (1994) and after (1996) implementing preventive measures.

Data from all 146 workers who were enrolled in 1996 were compared with $1-\mathrm{hp}_{\mathrm{ur}}$ values from a control group of 54 non-occupationally exposed male subjects, who were randomly sampled among the residents in Perugia, Central Italy. The percentage of smokers was similar in both workers and control subjects (37.7\% v $37.0 \%$, respectively).

All subjects gave their written informed consent and the study was approved by the Ethics Committee of the University of Perugia.

Details on $1-\mathrm{hp}_{\mathrm{ur}}$ sampling and analysis have been reported elsewhere. ${ }^{18}$ Briefly, $1-\mathrm{hp}_{\mathrm{ur}}$ concentrations were measured by high performance liquid chromatography coupled with fluorescence detection, after urine samples underwent enzymatic hydrolysis and a solid phase clean up according to Jongeneelen et al (1987). ${ }^{5}$ Measurements of $1-h p_{u r}$ were corrected for urinary creatinine.

STATISTICAL ANALYSIS

Statistical analysis was performed by SPSS for PC software. As the distributions of $1-\mathrm{hp}_{\mathrm{ur}}$ values were skewed, only non-parametric tests were used. Within subject comparisons were performed by the Wilcoxon matched pairs test. Data on 1-hp $\mathrm{p}_{\mathrm{ur}}$ excretion in different groups of workers and in the control group were analysed by the Mann-Whitney $U$ test. Differences were considered significant at $\mathrm{p}<0.05$.

\section{Results}

CURRENT 1-HP ${ }_{\mathrm{UR}}$ CONCENTRATIONS $v 1994$

CONCENTRATIONS

In the 103 workers, $1-\mathrm{hp}_{\mathrm{ur}}$ concentrations were lower in 1996 than in 1994 (median: $1.13 \mu \mathrm{g} / \mathrm{g}$ creatinine $v 1.80 \mu \mathrm{g} / \mathrm{g}$ creatinine, $\mathrm{p}=0.0001$ ).

When workers were divided into groups according to their job, $1-\mathrm{hp}_{\mathrm{ur}}$ concentrations were significantly lower in 1996 than in 1994 in workers at the green electrode unit and at the baking impregnation unit No 1 (fig 2). Compared with 1994 values, median $1-\mathrm{hp}_{\mathrm{ur}}$ concentration was about $-24 \% \quad(2.44 \mu \mathrm{g} / \mathrm{g}$ creatinine $v 3.20 \mu \mathrm{g} / \mathrm{g}$ creatinine, $\mathrm{p}=0.038$, $\mathrm{n}=9$ ) at the green electrode unit, and about $-37 \% \quad(2.03 \mu \mathrm{g} / \mathrm{g}$ creatinine $v \quad 3.20 \mu \mathrm{g} / \mathrm{g}$ creatinine, $\mathrm{p}=0.007, \mathrm{n}=18$ ) at the baking impregnation No 1 unit. The highest individual values were considerably lower in 1996 than in 1994 in each of these units (fig 2).

A reduction in $1-\mathrm{hp}_{\mathrm{ur}}$ concentration was also evident in laboratory workers, with median and highest individual values being, respectively, $30 \%$ and $65 \%$ less in 1996 than in $1994(0.70$ $\mu \mathrm{g} / \mathrm{g}$ creatinine $v 1.00 \mu \mathrm{g} / \mathrm{g}$ creatinine, $\mathrm{p}=0.05$, $\mathrm{n}=15$; and $1.31 \mu \mathrm{g} / \mathrm{g}$ creatinine $v 3.70 \mu \mathrm{g} / \mathrm{g}$ creatinine, respectively, fig 2).

In workers at the baking impregnation unit No 2, in end product finishing and in the power station, $1-\mathrm{hp}_{\mathrm{ur}}$ concentrations were similar in 1996 and in 1994 (fig 2).

The concentrations of $1-\mathrm{hp}_{\mathrm{ur}}$ from each group of workers enrolled for within subject comparisons did not significantly differ from the concentrations measured in other workers performing the same job but not considered for within subject comparisons (data not shown; Mann-Whitney $U$ test).

CURRENT 1-HP ${ }_{\mathrm{UR}}$ EXCRETION AT THE ELECTRODE PLANT $v$ CONTROL GROUP

Urinary 1-hp concentrations were significantly higher in each group of workers than in the control group ( $\mathrm{p}<0.001$ for any comparison). Concentrations in the 146 workers varied with the type of job (table).

The highest individual $1-\mathrm{hp} \mathrm{p}_{\mathrm{ur}}$ concentrations were between five and nine times higher in workers at the green electrode unit, at the two

Table 1 Urinary 1-hydroxypyrene in graphite electrode workers and in the control group

\begin{tabular}{|c|c|c|c|c|c|c|c|}
\hline & \multirow[b]{2}{*}{$n$} & \multicolumn{6}{|c|}{ 1-Hydroxypyrene ( $\mu g / g$ creatinine) } \\
\hline & & Median & Mean & $25 \%$ & $75 \%$ & Min & $\operatorname{Max}$ \\
\hline Electrode workers & 146 & 1.44 & 2.24 & 0.76 & 2.70 & 0.08 & 13.8 \\
\hline \multicolumn{8}{|l|}{ Unit: } \\
\hline Green carbon & 13 & $2.44^{\star}$ & 3.16 & 1.30 & 4.20 & 0.69 & 8.665 \\
\hline Baking impregnation 1 & 25 & $2.25^{\star}$ & 2.38 & 1.07 & 2.82 & 0.38 & 7.78 \\
\hline Baking impregnation 2 & 55 & $1.91^{\star}$ & 1.91 & 1.06 & 3.14 & 0.36 & 12.20 \\
\hline Finishing & 25 & $0.66^{\star}$ & 0.69 & 0.35 & 0.96 & 0.13 & 1.78 \\
\hline Laboratory & 18 & $0.66^{\star}$ & 0.60 & 0.28 & 0.85 & 0.08 & 1.31 \\
\hline Power station & 10 & $3.35^{\star}$ & 5.83 & 2.19 & 11.68 & 1.31 & 13.80 \\
\hline Control group & 54 & 0.13 & 0.19 & 0.05 & 0.24 & 0.01 & 1.56 \\
\hline
\end{tabular}

${ }^{\star} \mathrm{p}<0.001 v$ Control group. 


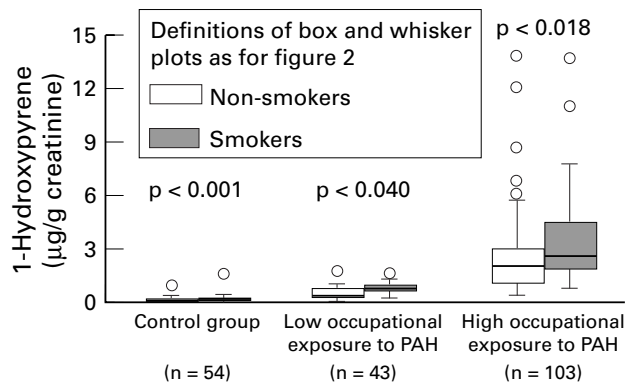

Figure 3 Effect of smoking on urinary 1-hydroxypyrene concentrations.

baking impregnation units, and in those in the power station than in the control group. Surprisingly, the highest median $(3.35 \mu \mathrm{g} / \mathrm{g}$ creatinine) and individual (13.80 and 13.70 $\mu \mathrm{g} / \mathrm{g}$ creatinine) $1-\mathrm{hp} \mathrm{pr}_{\mathrm{ur}}$ concentrations were found in workers in charge of the power station.

The highest $1-h p_{u r}$ concentrations in workers engaged in end product finishing and in laboratory analysis overlapped with the upper limit in the control group (table). Urinary 1-hp concentrations did not differ significantly in workers employed at the two baking impregnation units (table). No significant differences emerged in the $1-h p_{u r}$ concentrations in the 18 laboratory workers when concentrations in the eight workers engaged in producing small electrodes for quality testing were compared with the 10 workers performing different tasks (median: $0.72 \mu \mathrm{g} / \mathrm{g}$ creatinine $v 0,52 \mu \mathrm{g} / \mathrm{g}$ creatinine; $p=0,59$ ).

To assess the effect of smoking on $1-\mathrm{hp}_{\mathrm{ur}}$ excretion, the 146 workers were divided into two groups, a first group with low occupational exposure to PAHs (workers engaged in end product finishing and at the laboratory unit) and a second group with high exposure (workers at the green electrode and at the two baking impregnation units, and workers in the power station). Urinary 1-hp concentrations were significantly higher in smokers than in nonsmokers in the control group and in each of the two occupationally exposed groups (fig 3 ). The difference between the median $1-\mathrm{hp}_{\mathrm{ur}}$ concentration in smokers and in non-smokers was $0.13 \mu \mathrm{g} / \mathrm{g}$ creatinine in the control group, 0.34 $\mu \mathrm{g} / \mathrm{g}$ creatinine in workers with low occupational exposure, and $0.59 \mu \mathrm{g} / \mathrm{g}$ creatinine in workers with high exposure.

\section{Discussion}

This study shows that implementing preventive measures significantly reduced exposure to PAHs at a graphite electrode plant. Specifically, we found an overall reduction in median and peak 1-hp $\mathrm{ur}_{\mathrm{ur}}$ concentrations, which was most evident in workers employed in the green electrode unit, in the baking impregnation unit No 1, and in the laboratory (fig 2). In all these units preventive measures had been taken-for example, installing local exhaust ventilation systems, cleaning the metallic baskets of pitch residues. There had been no further modifications in the productive flow process, or in workwear policy. Moreover, we considered only workers with the same job and with similar smoking habits in 1996 as in 1994, thus avoiding the risk of misclassification of exposure to PAHs. We performed within subject comparisons of $1-h p_{u r}$ data, thus controlling for the relevant variation between people in activity of pyrene biotrasforming enzymes which might influence the results. ${ }^{1920}$ The effects of age and differences in exposure to PAHs from diet at the two sampling times could have only influenced 1-hp $\mathrm{ur}_{\mathrm{ur}}$ results marginally. ${ }^{20}$ Consequently we presume that the reduction in $1-h p_{u r}$ concentrations, which reflects total exposure to, and internal dose of PAHs, was due to the preventive measures.

However, despite an overall reduction, current exposure to PAHs at some units of the electrode plant (at the green electrode, at the two baking impregnation units, and at the power station) is still high, compared with workers engaged in other units (electrode finishing and laboratory analysis) and with the control group. Even though several local exhaust ventilation systems were installed, other sources of pitch dusts and vapours still exist in the electrode plant, and need to be controlled. Control of workwear policy might also be advisable, as experimental and field studies have shown that skin exposure greatly contributes to PAH intake and $1-\mathrm{hp}_{\mathrm{ur}}$ excretion. ${ }^{13}{ }^{1721}$ An intervention study on coal liquefaction workers showed that improvements in workwear policy may result in a significant reduction in $1-\mathrm{hp}_{\mathrm{ur}}$ excretion. ${ }^{16}$

We found high $1-\mathrm{hp}_{\mathrm{ur}}$ concentrations in workers engaged in processing raw materials, in extrusion, baking, and impregnation of the electrodes and in the power station (high exposure group). These findings concur with reports on graphite electrode plants in Belgium and Germany. ${ }^{22}$ However, exposure levels seem to be lower in the Italian plant. In fact 1-hp $\mathrm{pu}_{\mathrm{ur}}$ concentrations among workers with high exposure to PAHs at the Italian plant (geometric mean: $2.14 \mu \mathrm{g} / \mathrm{g}$ creatinine; median: 2.24 $\mu \mathrm{g} / \mathrm{g}$ creatinine; $\mathrm{n}=103$ ) were lower than in workers engaged in the extrusion of electrodes (geometric mean: 5.75 and $5.47 \mu \mathrm{g} / \mathrm{g}$ creatinine; $\mathrm{n}=5$ and 9 ; non-smoking and smoking workers, respectively) or in electrode impregnation (geometric mean: 7.99 and $9.58 \mu \mathrm{g} / \mathrm{g}$ creatinine; $\mathrm{n}=3$ and 5; non-smoking and smoking workers, respectively) at the Belgian plant. ${ }^{9}$ They were even lower than in workers engaged in processing raw materials (median: $9.6 \mu \mathrm{g} / \mathrm{g}$ creatinine; $\mathrm{n}=2$ ), or in electrode baking (median: $23.4 \mu \mathrm{g} / \mathrm{g}$ creatinine; $\mathrm{n}=30)$ and impregnation (median: $22.0 \mu \mathrm{g} / \mathrm{g}$ creatinine; $\mathrm{n}=9$ ) at the German plant. $^{22}$

We found that smoking increased $1-\mathrm{hp}_{\mathrm{ur}}$ concentrations in the control group and in the two occupationally exposed groups of workers, and that this increase rose with increased exposure to PAHs (fig 3). The more marked effect of smoking on $1-\mathrm{hp}_{\mathrm{ur}}$ excretion in the workers with higher exposure might indicate a synergistic effect between smoking and occupational exposure to PAHs. A similar effect has already been hypothesised in other studies, ${ }^{812} 15$ and three explanations are possible. First of all, smoking seems to modulate 
PAH metabolism, by enhancing the enzymatic biotransformation of pyrene into 1-hp. Recent in vitro studies have shown that the activity of the pulmonary enzyme pyrene 1-hydroxylase is, on average, 10 times higher in smokers than in current non-smokers. ${ }^{19}$ Secondly, smoking is known to reduce mucociliary clearance, and consequently might impair the removal from the lung of PAHs bound to particles. Thirdly, workers who smoke might remove their protection masks more often than nonsmokers. Even though smoking significantly increases $1-\mathrm{hp}_{\mathrm{ur}}$ concentrations, it affects concentrations in the workers in this plant much less than occupational exposure (fig 3).

This study confirms that $1-\mathrm{hp}_{\mathrm{ur}}$ is a useful biological marker of exposure to PAHs and can be successfully used to assess the efficacy of preventive measures in work environments polluted by PAHs. Unfortunately the biological exposure limits or action levels for $1-\mathrm{hp}_{\mathrm{ur}}$ remain to be established. Jongeneelen in 1992 proposed a tentative biological limit of $4.4 \mu \mathrm{g} / \mathrm{g}$ creatinine for coke oven workers - that is, the $1-\mathrm{hp}_{\mathrm{ur}}$ concentration excreted when these workers are exposed at $0.2 \mathrm{mg}$ benzene soluble matter $/ \mathrm{m}^{3}$ (the ACGIH threshold limit value time weighted average for benzene soluble matter of coal tar pitch volatiles). ${ }^{23}$ Similarly, Van Rooij et al in 1993 estimated a biological limit of $6.2 \mu \mathrm{g} 1-\mathrm{hp}_{\mathrm{ur}} / \mathrm{g}$ creatinine for coke oven workers-that is, the $1-\mathrm{hp}_{\mathrm{ur}}$ concentration excreted when these workers are exposed at 2 $\mu \mathrm{g}$ benzo(a)pyrene $/ \mathrm{m}^{3}$ (the German technical guiding concentration). ${ }^{21}$ These two limits have been criticised, ${ }^{22}$ on the grounds that biological exposure indices for $1-\mathrm{hp}_{\mathrm{ur}}$ should not be derived from a correlation between the internal dose and the airborne exposure to PAHs, given the dermal absorption of PAHs in many work environments. Buchet et al in 1995 proposed the value of $2.7 \mu \mathrm{g} 1-\mathrm{hp}_{\mathrm{ur}} / \mathrm{g}$ creatinine as the limit below which $1-\mathrm{hp}_{\mathrm{ur}}$ concentrations "should preferably be kept", because it seems to be the threshold for increased cytogenetic effects in peripheral blood lymphocytes of non-smoking workers compared with a reference population. ${ }^{24}$ This biological limit is rather attractive as it derives from correlations between the internal dose and the lack of health effect (no effect level). However, the relevance of the measured end points to the actual health risks - for example, lung neoplasm - need to be better evaluated. More recently, Zober and Will assumed the upper reference limit of 1-hp $\mathrm{pur}_{\mathrm{ur}}$ concentrations in a population of smokers who were not occupationally exposed to PAHs (2.5 $\mu \mathrm{g} 1-\mathrm{hp}_{\mathrm{ur}} / \mathrm{g}$ creatinine) as the action level for a biological monitoring programme. ${ }^{25}$ Angerer et al suggested using the 90th percentile of the results of biological monitoring as an action level for corrective measures, once dermal exposure had been reduced as much as possible. ${ }^{22}$

According to the Council Directive 90/394/EEC, ${ }^{26}$ current scientific evidence cannot identify a dose for a carcinogen below which cancer risk will not exist. Therefore, in the light of the assumption that a reduction of exposure and absorption of carcinogenic PAHs will none the less reduce this risk, we support the endorsement of action levels aiming at reducing workers' $1-\mathrm{hp}_{\mathrm{ur}}$ excretion to the ranges encountered in the general population.

In the electrode plant investigated in this report some groups of workers still excreted higher $1-\mathrm{hp}_{\mathrm{ur}}$ concentrations than nonoccupationally exposed subjects. Further preventive measures are needed to minimise exposure to PAHs and the risk of adverse health effects. These measures should include the removal of other sources of PAH volatiles, an appropriate workwear policy, and an information programme on health risks associated with exposure to PAHs and smoking habits.

We thank Dr GA Boyd for her invaluable help.

1 International Agency for Research on Cancer. IARC monographs on the evaluation of the carcinogenic risk to humans. Polynuclear aromatic compounds, part 1. Vol 32. Chemical, environmental and experimental data. Lyon: IARC, 1983.

2 International Agency for Research on Cancer. IARC monographs on the evaluation of the carcinogenic risk to humans. Polynuclear aromatic compounds, part 3. Vol 32. Industrial exposures in aluminium production, coal gasification, coke production, and iron and steel founding. Lyon: IARC, 1984.

3 Lindstedt G, Sollenberg J. Polycyclic aromatic hydrocarbons in the occupational environment. With special reference to benzo(a)pyrene measurements in Swedish industry. Scand $\mathcal{F}$ Work Environ Health 1982;8:1-19.

4 International Agency for Research on Cancer. IARC monographs on the evaluation of the carcinogenic risk to humans. Overall evaluations of carcinogenicity: an updating of IARC Overall evaluations of carcinogenicity: an updating of IARC
monographs. Vol 1 to 42, supplement 7. Lyon: IARC, 1987.

5 Jongeneelen FJ, Anzion RBM., Henderson PT. DeterminaJongeneelen FJ, Anzion RBM., Henderson PT. Determina-
tion of hydroxylated metabolites of polycyclic aromatic tion of hydroxylated metabolites of polycyclic aromatic
hydrocarbons in urine. 7 Chromatogr 1987;413:227-32.

hydrocarbons in urine. $\mathcal{F}$ Chromatogr 1987;413:227-32.
6 Jongeneelen FJ, Azion RBM, Scheepers PTJ, et al. 1-Hydroxypyrene in urine as a biological indicator of exposure to polycyclic aromatic hydrocarbons in several work environments. Ann Occup Hyg 1988;1:35-43

7 Jongeneelen FJ, Scheepers PTJ, Groenendijk A, et al. Airborne concentrations, skin contamination, and urinary metabolite excretion of polycyclic aromatic hydrocarbons among paving workers exposed to coal tar derived road tars. Am Ind Hyg Assoc f 1988;49:600-7.

8 Jongeneelen FJ, van Leeuwen FE, Oosterink S, et al. Ambient and biological monitoring of coke oven workers: determinants of the internal dose of polycyclic aromatic hydrocarbons. Br F Ind Med 1990;47:454-61.

9 Buchet JP, Gennart JP, Mercado-Calderon F, et al. Evaluation of exposure to polycyclic aromatic hydrocarEvaluation of exposure to polycyclic aromatic hydrocar-
bons in a coke production and a graphite electrode manubons in a coke production and a graphite electrode manu1-hydroxypyrene as a biological indicator of exposure. $\mathrm{Br} \mathcal{F}$ Ind Med 1992;49:761-8.

10 Omland Ø, Sherson D, Hansen ÅM, et al. Exposure of iron foundry workers to polycyclic aromatic hydrocarbons: benzo(a)pyrene-albumin adducts and 1-hydroxypyrene as biomarkers for exposure. Occup Environ Med 1994;51:513-

11 Kuljukka T, Vaaranrinta R, Mutanen P, et al. Assessment of occupational exposure in an Estonian coke oven plant correlation of total external exposure to internal dose measured as 1-hydroxypyrene concentration. Biomarkers 1997;2:87-94.

12 van Schooten FJ, Jongeneelen FJ, Hillebrand MJX, et al. Polycyclic aromatic hydrocarbon-DNA adducts in white blood cell DNA and 1-hydroxypyrene in the urine from aluminum workers: relation with job category and synergistic effect of smoking. Cancer Epidemiol Biomarkers Prev 1995;4:69-77.

13 Quinlan R, Kowalczyk G, Gardiner K, et al. Urinary 1-hydroxypyrene: a biomarker for polycyclic aromatic Med 1995;45:63-8.

14 Goen Th, Gundel J, Schaller K-H, et al. The elimination of 1-hydroxypyrene in the urine of the general population and workers with different occupational exposure to PAH. Sci Total Environ 1995;163:195-201.

15 Øvrebø S, Haugen A, Fjeldstad PE, et al. Biological monitoring of exposure to polycyclic aromatic hydrocarbon in an electrode paste plant. F Occup Med 1994;36:303-10.

16 Quinlan R, Kowalczyk G, Gardiner K, et al. Exposure to polycyclic aromatic hydrocarbons in coal liquefaction workers: impact of a workwear policy on excretion of urinary 1-hydroxypyrene. Occup Environ Med 1995;52: 600-5.

17 van Rooij JGM, Van Lieshout EMA, Bodelier-Bade MM, et al. Effect of the reduction of skin contamination on the internal dose of creosote workers exposed to polycyclic aromatic hydrocarbons. Scand F Work Environ Health 1993; 19:200-7.

18 Marchionna G, Valenti E, Paolemili O, et al. Valutazione dell'assorbimento di idrocarburi policlici aromatici medi- 
ante dosaggio dell'1-OH-pirene urinario nei lavoratori di una fabbrica di elettrodi di grafite. Med Lav 1996;87:162 70.

19 Vainio H, Elovaara E, Luukkanen L, et al. Expression and co-induction of CYP1A1 and UGT1 ${ }^{\star} 6$ in human lungs. Eur $\mathcal{F}$ Drug Metab Pharmacokinetics 1995;special issue: 47-8.

20 van Rooij JGM, Veeger MMS, Bodelier-Bade MM, et al. Smoking and dietary intake of polycyclic aromatic hydrocarbons as sources of interindividual variability in the baseline excretion of 1-hydroxypyrene in urine. Int Arch Occup Environ Health 1994;66:55-65.

21 van Rooij JGM., Bodelier-Bade MM, Jongeneelen FJ. Estimation of individual dermal and respiratory uptake of polycyclic aromatic hydrocarbons in 12 coke oven workers. Br F Ind Med 1993;50:623-32.

22 Angerer J, Mannschreck C, Gundel J. Occupational exposure to polycyclic aromatic hydrocarbons in a graphite-electrode producing plant: biological monitoring of 1-hydroxypyrene and monohydroxylated metabolites of phenanthrene. Int Arch Occup Environ Health 1997;69:32331 .

23 Jongeneelen FJ. Biological exposure limits for occupational exposure to coal tar pitch volatiles at cokeovens. Int Arch Occup Environ Health 1992;63:511-6.

24 Buchet JP, Ferreira Jr M, Burrion JB, et al. Tumor makers in serum, polyamines and modified nucleosides in urine, and cytogenetic aberrations in lymphocytes of workers exposed to polycyclic aromatic hydrocarbons. Am f Ind Med 1995; 27:523-43.

25 Zober A, Will W. Biological monitoring and risk assessment in occupational settings. Int Arch Occup Environ Health 1996;68:389-93.

26 Council Directive 90/394/EEC, 28 June 1990. Protection of workers from the risks related to exposure to carcinogens at work. Official Fournal of the European Communities 1990; L196/26.7.1990:1-7.

\section{Rejected manuscripts}

From February 1994, authors whose submitted articles are rejected will be advised of the decision and one copy of the article, together with any reviewer's comments, will be returned to them. The fournal will destroy remaining copies of the article but correspondence and reviewers' comments will be kept. 